http://dx.doi.org/10.14393/HeP-v30n57-2017-8

\title{
O OFICIO DO HISTORIADOR: REFLEXÕES SOBRE O CONCEITO DE PASSADO EM SUAS DIMENSÕES SOCIAIS E HISTÓRICAS
}

\author{
João Paulo Pereira Coelho* \\ José Joaquim Pereira Melo**
}

RESUMO: O uso do passado como uma experiência legitimadora de interesses e demandas do presente tem suscitado debates por parte dos historiadores. Diante de tal questão, analisamse as diferentes formas de apropriação do passado pelos homens, considerando-se os enfrentamentos sociais ocorridos historicamente. Entende-se que essas lutas fazem com que o passado seja objeto ora de negação, ora de reiteração no presente. Tal antagonismo exprime a complexidade das relações humanas, que são constituídas por meio da totalidade social na qual o homem é formado. Cabe, portanto, ao historiador, problematizar o entendimento que a sociedade faz a respeito do passado e situá-lo para além das representações que os homens fazem de si mesmos.

PALAVRAS-CHAVE: Teoria da História. Formação Humana. Historiografia.

ABSTRACT: Use the past as a legitimizing experience of interests

* Professor de História da Educação e Políticas Educacionais do Curso de Pedagogia da Universidade Estadual do Paraná. Doutor em Educação: História e Historiografia da Educação pela Universidade Estadual de Maringá. Contatos: joaoppc22@hotmail.com; joaoppc0@gmail.com

** Professor do Departamento de Fundamentos da Educação e do Programa de Pos-Graduação em Educação da Universidade Estadual de Maringá. Doutor em Educação pela UNESP. Contatos: pereirameloneto@hotmail.com 
and actual demands has evoked debates by the historians. Faced with this question, we analyze the different forms of past ownership by men, regarding the social clashes occurred historically. It is understood that these struggles make that the past be a denial object and in other case a reiteration object in the present. Such antagonism expresses the complexity of human relationships that are made through the social totality in which the human being is formed. So, it concerns to the historian to problematize the understanding that society has about the past and to place it beyond the representations that men make about themselves.

KEYWORDS: History Theory. Human Formation. Historiography.

\section{Introdução}

As reflexões sobre o sentido do passado para o ofício do historiador implicam, inicialmente, uma abordagem do conceito de tempo, o qual tem inquietado os historiadores indistintamente de suas orientações teórico-metodológicas.

Analisando-se o conceito de tempo como uma representação simbólica, e, portanto, distinta da expressão concreta da vida humana e dos ciclos da natureza, observa-se que esse expediente foi concebido tardiamente com o advento da indústria. O tempo regulado pelo relógio e pelo calendário, aplicado de maneira imperativa sobre a existência do homem, tinha como objetivo o controle e a exploração do homem dentro e fora do espaço da fábrica: "Assim, as máquinas do tempo (o relógio) abrem caminho para a sociedade das máquinas” (ATTALI, 1985, p. 67).

À medida que o tempo se colocou como o referencial para a mensuração da expropriação da força de trabalho, instaurouse um processo de transformações na forma de vida dos trabalhadores. Estes foram submetidos a esse tempo relógio, que sincroniza suas existências com as requisições temporais do trabalho, suas vivências sociais com as obrigações decorrentes 
dessa nova forma reguladora do tempo para a execução do seu ofício no espaço de produção (HOBSBAWM, 2004). Conforme o relato de um marceneiro britânico, que expõe em um bilhete a um amigo as novas relações de trabalho a que foi submetido, em 1848: "o tempo não mais nos pertence, por isso amanhã não poderei ir à sua casa, mas se você puder vir à praça da Bolsa, entre duas e duas e meia, nós nos encontraremos como sombras miseráveis nas bordas do inferno" (PIKE, 1974, p. 67).

As novas articulações entre tempo e trabalho devem ser consideradas nas vivências sociais do historiador do presente. Este deve ter consigo o entendimento de que o conhecimento ou a análise da História têm como base sua própria época, de forma que, ao dialogar com o passado, ele contemple os embates e as contradições que são próprias do seu presente.

Em outros termos, a pesquisa acadêmica não se desenvolve de forma alheia às práticas sociais cotidianas dos homens, uma vez que sua intencionalidade está, em parte, intimamente ligada ao exercício do historiador.

Guardadas as devidas proporções e considerando as identificações estabelecidas entre o historiador e sua época, entende-se que, para que se possa realizar uma reflexão a respeito do sentido do passado - referencial inerente a esse ofício -, é necessário ir ao encontro de sua historicidade. "O tempo, como categoria central da História", ao ser analisado, "não se apresenta, porém, como uma unidade, uma síntese", mas deve ser "entendido em seus momentos constitutivos" (CASTANHO, 2010, p. 63), como resultado e produto das relações humanas, das práticas sociais promovidas pelos homens em seus enfrentamentos e embates, em suas lutas. Ou seja, o homem fazendo sua história.

Todavia, buscar o entendimento da forma como a sociedade se apropria do passado é um exercício fundamental para o oficio do historiador. Assim, passado e memória são conceitos que: "apesar de oscilantes, são noções fundamentais para o trabalho histórico, porque operam exatamente no coração da mudança" (CASTANHO, 2010, p. 64).

Neste âmbito, os subsídios da memória à legitimação do 
passado constituem-se uma discussão profícua. Por um lado, na contemporaneidade caracterizada pelo tempo urbano e industrial, o passado a ser conformado pela memória constituiu-se, por vezes, como um instrumento para a legitimação da história dos vencedores - pautada, por exemplo, por ideais nacionalistas e de progresso. Por outro, a valorização da memória promovida por grupos sociais minoritários, quando circunscrita à individualidade e à subjetividade do sujeito, perde complexidade, desconectando-se de experiências sociais em uma perspectiva cultural mais ampla.

Assim, não se pode desconsiderar que a definição de passado é sempre instável, volátil e, em muitos casos, até mesmo comprometida com interesses que se impõem pelo momento histórico em que o historiador vive: legitimar a ordem posta, em termos de produção e reprodução da vida, ou negar sua excelência como referencial para a nova ordem social que se pretende efetivar, visto que aquela já não atende às demandas que se colocam para seu tempo.

\section{O conceito de passado: considerações históricas e sociais}

A destruição do passado - ou melhor, dos mecanismos sociais que vinculam nossa experiência pessoal à das gerações passadas é um dos fenômenos mais característicos e lúgubres do final do século XX. (HOBSBAWM, 2010, p. 13).

Faz parte do processo de construção da história humana a compreensão de que o passado é expressão da vida dos homens ao longo dos tempos. Esta consciência a respeito do tempo passado pôde ser constituída com base nas vivências sociais, em espaços compostos pelas experiências humanas de sujeitos pertencentes a diferentes gerações.

A consciência do passado desenvolveu-se, portanto, por meio de trocas sociais e culturais em períodos históricos em que os mais velhos, como expressão maior das experiências da vida comunitária em épocas pretéritas, constituíam-se como 
mediadores entre o passado e o presente. Assim, formavam as novas gerações para terem consciência de que eram membros de uma comunidade, cuja dimensão era coletiva e social (MARX, 1986).

A defesa da continuidade cultural e social que compõe a história humana, nesse sentido, não significa uma negação do processo de mudanças que a humanidade vivencia e, por extensão, transforma. Faz parte da busca pela preservação da existência o comprometimento do homem com a reiteração da cultura transmitida ao longo dos tempos (HOBSBAWM, 2004). Foi a partir dela que se estabeleceu um novo tempo, uma nova ordem social.

Em suma, [...] é possível concluir que o novo só se estabelece na luta contra as velhas formas de comportamento, na utilização de materiais, suportes e subsídios do passado para justificar ou sedimentar os comportamentos emergentes. Por outro lado, isso permite também identificar as marcas que o passado deixa nos homens de outras épocas e em que circunstâncias isso acontece. (PEREIRA MELO, 2010, p. 27-28).

Assim, as heranças do passado são as bases para a manutenção e a sobrevivência das gerações vindouras, ou seja, para a perpetuação de todo um legado social cultural produzido e acumulado por um povo.

O sujeito é, portanto, expressão dessa complexidade social, uma vez que, ao mesmo tempo em que vai ao encontro das novas demandas impostas pelo momento histórico vivido, vivencia particularmente em sua cultura - experiências individuais que reiteram seus laços com o passado (HOBSBAWM, 2010) e garantem sua vigência e perenidade em outras gerações. Assim: “Esse 'ir e vir', presente-passado, exige um 'exorcismo' das influências e dos 'preconceitos' da dinâmica social do presente. Para se projetar em momentos históricos distanciados no tempo, [...] é necessário encontrar um modo peculiar de entender a realidade. (PEREIRA MELO, 2010, p.22-23). 
Isso é expressão do reconhecimento de que a consciência de humanidade está revestida de singularidades, ainda que esse valor seja constituído com base em toda a produção humana do passado. O homem é um ser singular e, ao mesmo tempo, social e histórico, inserido em uma totalidade sem fronteiras:

A memória individual constitui o fundamento da noção do eu, daquilo a que chamamos identidade pessoal. Isso não significa que seja isenta de aspectos da memória social do grupo ou da classe social de que o indivíduo é originário. Pelo contrário; no indivíduo subsistem os fundamentos de sua identidade pessoal com traços da cultura em que ele foi formado, e em que continua sendo formado. (CASTANHO, 2010, p. 57).

Diante dessa complexidade humana, o desafio que se apresenta ao historiador de ofício é analisar o passado em sua transformação e com base no movimento que esse próprio passado apresenta (CASTANHO, 2009). Com isso, o retorno ao passado implica tanto a busca pela conservação de suas heranças culturais e sociais quanto a gênese de suas transformações.

A crença de que a "sociedade tradicional" seja estática e imutável é um mito da ciência social vulgar. Não obstante, até um certo ponto de mudança, ele pode permanecer tradicional: o molde do passado continua a modelar o presente, ou assim se imagina. (HOBSBAWM, 2004, p. 25).

A concepção de passado, portanto, não se reduz à ideia de "conservação", mas abrange a de que ele é um valor que faz dos homens seres históricos, comprometidos com suas heranças culturais e sociais, mesmo em contextos em que já são identificadas rupturas em suas estruturas. É na busca pelo entendimento dessa dinâmica que se pode compreender o "coração da mudança" (CASTANHO, 2010, p. 64) que está em curso, as circunstâncias nas quais a sociedade não tinha precisado de maneira objetiva a si mesma e as transformações que suas vivências já comportavam: 
Mas sempre terá interstícios, ou seja, matérias que não participam do sistema da história consciente na qual os homens incorporam, de um modo ou de outro, o que consideram importante sobre a sociedade. A inovação pode ocorrer nesses interstícios, desde que não afete automaticamente o sistema e, portanto, não se oponha automaticamente: "não é desse jeito que as coisas sempre foram feitas”. (HOBSBAWM, 2004, p. 23).

É necessário considerar que essas transformações sociais em curso, quando atingem um maior amadurecimento, um ponto culminante, são externadas pelos sujeitos de maneira consciente. Este estado de mudanças é resultado da maior complexidade que as relações sociais vão adquirindo, complexidade esta que acirra as contradições contidas no interior da sociedade (MARX, 1990).

Característica dessas novas demandas sociais e econômicas advindas desses processos de mudanças já efetivadas - as quais se desdobram em embates entre as classes sociais emergentes e as práticas sociais e políticas que garantiam a manutenção da ordem posta pelos setores sociais até então hegemônicos - foi a Revolução Francesa.

O legado histórico do medievo, como o renascimento do comércio e o desenvolvimento das cidades, havia criado necessidades que o Estado monárquico francês não conseguiu suprir (SAINT-JUST, 1996). Para a burguesia que se desenvolve nos tempos modernos, e que atingia um alto grau desenvolvimento econômico, tornava-se insustentável manter seus negócios subordinados aos interesses do Estado absolutista, alinhado aos privilégios da nobreza e do clero. Portanto, as contradições entre o Antigo Regime e as necessidades do homem burguês tornaram a estrutura social francesa vulnerável.

Apesar de ocupar um posto privilegiado, a situação da nobreza não era confortável. A manutenção de seus títulos de nobreza exigia altos investimentos. Ainda, como não tinham experiência administrativa, não possuíam grandes habilidades para gerenciar suas fortunas (SAINT-JUST, 1996). Diante destes problemas enfrentados, recorreriam aos privilégios oferecidos 
pelo Estado, na tentativa de manter seu status quo. Assim, os cargos diplomáticos e administrativos que antes eram ocupados pela burguesia - mais diligentes nas questões administrativas passaram a ser preenchidos pela nobreza.

Embora a burguesia não cessasse de crescer em número e em riqueza, desde o início do século, era cada vez mais despojada das grandes funções públicas. Ao passo que no século XVII a burguesia havia fornecido ao Estado, ministros, como Colbert, a maioria dos intendentes, vários magistrados aos parlamentos, oficiais à marinha e ao exército, prelados a igreja, no século XVIII, todos esses postos passaram a ser reservados a nobreza. (GODECHOT, 1976, p. 34).

A burguesia identificou na monarquia - com sua forma de administrar para os privilegiados - valores que fomentavam os entraves ao seu pleno desenvolvimento. Esta percepção a respeito do Estado monárquico, ainda que em dimensões diferenciadas, atingia tanto a burguesia como os trabalhadores. Neste sentido, Michelet diria que "houve um acordo completo sem reserva, uma situação simples, a nação de um lado, e o privilégio do outro" (MICHELET, 1989, p. 95).

Desenvolveu-se um estado de enfrentamento que fez com que os atores sociais promotores da mudança de então (a burguesia) deixassem de orientar sua existência pelas práticas sociais e culturais tidas como pretéritas (HOBSBAWM, 2010). Estas, por seu turno, já que envelhecidas, não atendiam mais às necessidades que se colocavam para os homens, o que levou a burguesia à concepção de que o passado não era uma vivência com articulações com o seu presente. Este antagonismo evidencia que as transformações sociais se inserem em uma dinâmica de demandas e preocupações, por vezes, contraditórias. Assim, com "o estudo dessas relações, é possível observar que, em seu bojo, emergem atores sociais que promovem a paulatina negação do modelo envelhecido e, ao mesmo tempo, desencadeiam um processo de elaboração do que seria o novo "(PEREIRA MELO, 2010, p. 27). 
Nesse novo espaço de enfrentamentos, as transformações desencadeadas pela burguesia no âmbito econômico passaram a compor a estrutura, no caso, da sociedade francesa. A partir de então, as forças sociais emergentes começaram a se sobressair no último espaço de resistência da ordem social em declínio: a política. Neste âmbito, as conquistas da burguesia desencadearam, por fim, a defesa de uma ruptura sistemática com os valores políticos que representavam esse passado a ser superado.

Vale lembrar que os tempos que antecederam a Revolução Francesa compuseram a gênese dos princípios de troca capitalistas, os quais foram se efetivando ao longo da história humana até se tornarem suficientemente organizados para subsidiar um enfrentamento polarizado entre burguesia, representante de uma "nova ordem social", a aristocracia e o alto clero, que capitaneavam a "velha ordem social" (MARX; ENGELS, 1990). Contudo, a revolução colaborou para que as experiências constituídas em épocas anteriores deixassem de compor a base na qual o homem burguês fundamentaria seu devir histórico.

Vimos, portanto, que os meios de produção e de troca, nos quais a burguesia erigiu-se, foram geradas na sociedade feudal. Em um certo estágio do desenvolvimento desses meios de produção e de troca, as condições sob as quais a sociedade feudal produziu e trocou, a organização feudal da agricultura e da indústria manufatureira, resumindo, as relações de propriedade feudais, tornaram-se não mais compatíveis com as forças produtivas já desenvolvidas. Tornaram-se grilhões. (MARX; ENGELS, 1990, p. 18).

O entendimento de que o passado expressa diferenciações de sentido relacionadas a rupturas com as questões econômicas não significa inseri-lo em uma dinâmica de progresso (CASTANHO, 2009). A sociedade de cada época, em um dado momento, passa a comportar um grau de amadurecimento e são seus embates econômicos que oferecem ao historiador a possibilidade de compreender tal processo de forma mais objetiva. 
Diante de transformações estruturais, é, portanto, infrutífera qualquer tentativa de restabelecer o passado tal qual ele ocorreu, ainda que seja recorrente, particularmente entre as classes sociais em declínio, o clamor pela restauração de valores de uma ordem pretérita jurídica e social.

No seio de uma nova ordem estabelecida, reiteram-se vozes dissonantes revestidas de saudosismo de um tempo agonizante ou já liquidado, muitas vezes romantizado, tendo em vista que "a hegemonia de uma forma (mudança histórica) não exclui a persistência, em diferentes meios e circunstâncias, de outras formas de sentido do passado" (HOBSBAWM, 2004, p. 35).

Constitui-se, desta maneira, a concepção de que o passado detém uma lição, arquivada no tempo e que não pode ser esquecida, à qual se recorreria no momento em que se fizesse necessária. A sociedade, ao não estabelecer este passado como uma diretriz para o presente, retiraria a autoridade da história para continuar operando em favor da "manutenção da ordem".

Observa-se que o sentido do passado, defendido no seio das classes que buscam sua conservação, apresenta-se revestido de valores que pretensamente seriam essenciais à vida coletiva, quando, de fato, essas classes, em primeira instância, lutam pela manutenção de seu poder:

O passado é um elemento essencial, talvez o essencial nessas ideologias. Se não há um passado satisfatório, sempre é possível inventá-lo [...]. O passado legitima. O passado fornece um pano de fundo mais glorioso a um presente que não tem muito o que comemorar. (HOBSBAWM, 2004, p. 17).

Como expressão de uma verdade essencial, o passado é tido como detentor de uma grandiosidade ideal, sem contradições, pois a contrariedade está em concordância com o presente - esse sim, marcado pelas incertezas, inseguranças e medos que caracterizam a nova ordem social, em processo de estabelecimento ou até mesmo já estabelecida.

Diante da impossibilidade da recriação de relações sociais 
e culturais que o passado comportou, observam-se, conforme já referido, tentativas de reescrevê-lo, sempre tendo em vista buscar, intencionalmente ou não, um referencial de excelência para cumprir as necessidades sociais do presente. Essas tentativas de reafirmar momentos do passado ocorrem especialmente quando sua pretensa grandiosidade começa a se dissipar ou já não apresenta caráter homogêneo.

Por vezes, o processo de ressignificação da história se desenvolve com base na defesa de princípios nacionalistas, como ocorreu, a exemplo, nos movimentos nacionalistas do século $X X$, em particular na Alemanha. A composição da identidade alemã, que passou por um período de amadurecimento ao longo do século XIX, foi resultado, em grande medida, de seu vigor econômico, político e cultural. Contudo, a Primeira Grande Guerra (1914-1918) anunciou para a Alemanha um período de derrotas que acabariam por abalar a autoconfiança que, construída ao longo do passado (HOBSBAWM, 2010), dera ao povo alemão a ideia de grandeza e superioridade diante dos demais povos.

Em 1918, com o fim da guerra, diante da derrota sofrida, a prosperidade sem fronteiras culturais e políticas parecia sucumbir e isso desconstruiu uma identidade cultural tecida historicamente pela nação alemã ao longo do tempo. Acrescentam-se as significativas perdas territoriais e a fragilização de uma identidade nacional fundada em conquistas que fizeram dos alemães um povo reconhecido e temido por seus feitos expansionistas.

O triunfo de Hitler, a partir de 1933, não teria tomado contornos de um movimento mais amplo se o nacionalismo não tivesse se constituído como um elemento basilar dos pretensos princípios renovadores do estado alemão. Da mesma forma, o exercício de "reescrever" a própria história alemã não se sustentaria internacionalmente se o nacionalismo não fosse ao encontro dos anseios de líderes de países europeus, que viam no protagonismo internacional do nascente nazismo um caminho para também trilharem (HOBSBAWM, 2010).

Sem essa busca comum por reinstituir no ocidente um protagonismo histórico a partir de "revanches" de caráter 
nacionalista, não seria razoável que líderes conservadores não fascistas achassem que serem identificados como ligados à Alemanha "pela mesma ideologia" - como afirmou Salazar, em Portugal, em 1940 - fosse de fato algo agregador.

Assim, o estado nazista foi buscar na Idade Média uma narrativa que legitimasse o III Reich, vigente entre 1933 a 1945, bem como o império constituído por nações conquistadas. Esse exercício tinha por fim passar à população alemã que o seu governo representava a continuidade do Sacro Império Romano Germânico, o I Reich. Dessa forma, punha-se em tela a superioridade e a nobreza dos alemães frente aos povos europeus. Ao elaborar essa narrativa, Hitler objetivava dar vigor à identidade e ao nacionalismo da população e, assim, dar credibilidade ao III Reich, ${ }^{1}$ ao apresentálo como o governo que estava recuperando um passado glorioso, marcado por conquistas, que havia feito da nação alemã superior e temida.

Mas que relação mantém então o presente, e, sobretudo, a moderna cultura alemã, com o antigo mundo helênico? Após Winckelmann, Lessing e o Homero de Voss, formou-se a ideia de que entre o espírito helênico e o espírito alemão existia um "sagrado vínculo nupcial", uma relação e uma compreensão toda especial, como nenhum outro povo europeu do ocidente moderno. (BURCKHARDT, 2010, p. 176).

Considerando esse processo de "recuperação" dos eventos históricos, é de particular significado que, durante a Segunda Grande Guerra (1939-1945), Hitler tivesse exigido que a França assinasse sua carta de capitulação no reconhecido vagão de trem em que a Alemanha havia assinado sua rendição em 1918 (HOBSBAWM, 2010). Ainda que esse fato possa ser concebido, simbolicamente, como uma marca da retomada do sentimento de orgulho nacional alemão, ele expressa também uma tentativa de (re)instituir um passado glorioso para os alemães à altura de sua tradição "helênica".

1 Importa considera que a unificação alemã, em 1870, marca o surgimento do II Reich, que se estendeu até o final da primeira guerra mundial. 
O que se evidencia nesses eventos, muito mais do que qualquer sucesso na recriação do passado, é uma sobreposição de eventos históricos, considerados capazes de atender à necessidade de regeneração do orgulho nacional perdido. Um novo fato, carregado de representações emocionais, é utilizado para ressignificar, à luz do presente, um momento histórico do passado que, todavia, não pode ser apagado nem refeito, pois qualquer tentativa de restaurar a História só pode ser concebida como farsa (MARX, 1997).

Cabe, então, considerar que a história como expressão das transformações sociais, como resultado de um processo de lutas, não se submente passivamente a manipulações, contudo estão sujeitas a serem "manejadas" ao encontro de um ideário em ascensão em determinados momentos históricos. A história, neste contexto, pode ser esvaziada de complexidade, perdendo, assim, vivacidade; uma vez que a pertença do sujeito aos "novos tempos", a saber, o tempo em prol da ressignificação do sentido de cidadania e estado, passa a ser circunscrita ao que deve ser reiterado ou suplantado de seu passado.

\section{O retorno ao passado em suas diferentes finalidades}

As tentativas de se fazer uso do passado para legitimar valores sociais do presente são recorrentes, já que aparecem em diferentes épocas históricas. Por mais que seus objetivos, a princípio, pareçam paradoxais, elas transitam entre suplantar o passado e se apropriar de suas tradições para atender às demandas do presente.

Os novos burgueses buscam pedigrees, as novas nações ou movimentos anexam a sua história exemplos de grandeza passadas na razão direta do que sentem estar faltando dessas coisas em seu passado real - quer esse sentimento seja ou não justificado. A pergunta mais interessante relativa a tais exercícios genealógicos é se ou quando tonam-se dispensáveis. (HOBSBAWM, 2004, p. 23). 
Ainda que esse retorno tenha como motivação as articulações existentes entre passado e presente, desconsidera-se, nesse percurso, a historicidade dessas tradições (CASTANHO, 2010) - mais do que sua história, busca-se uma identidade:

O que os marxistas modernos ganharam ou ganham com o conhecimento de que havia rebeliões de escravos na Roma Antiga que, mesmo supondo-se que tivessem metas comunistas, estavam, segundo a própria análise desses marxistas, fadadas ao fracasso ou a produzir resultados que trariam escasso suporte às aspirações dos comunistas modernos? É evidente que a sensação de pertencer a uma tradição antiquíssima de rebelião fornece satisfação emocional. (HOBSBAWM, 2004, p. 33).

A configuração da identidade de um grupo deriva da formação de sua autoconsciência, da capacidade de seus integrantes expressarem um conjunto de características tidas como próprias, particulares, e, da mesma forma, de se sentirem pertencentes a uma esfera social e histórica mais ampla. Nessa esfera, a tradição, cujos valores são compostos pela memória coletiva, é convocada a dar coesão ao tecido social que compõe a identidade dos homens, principalmente nos momentos em que suas convicções sobre os laços de pertencimento a determinada classe ou grupo parecem incertas (HOBSBAWM, 2010).

Em um momento em que a constituição da identidade se encontra em um estágio inicial, ou frágil, a tradição, por estar essencialmente articulada à experiência e à sabedoria moral, é utilizada para reforçar os laços de pertencimento dos homens a um determinado grupo (CASTANHO, 2010).

Da mesma forma, a evocação das tradições por parte de muitas nações não se caracteriza simplesmente pela busca do passado, pela tentativa de apresentar as origens de seu povo. O passado, ao se constituir como uma memória comum, é particularmente fecundo quando expressa uma descendência genealógica tida como nobre, que seja revestida de uma pretensa pureza, linearidade e coesão, o que, se considerado da perspectiva da lógica dos enfrentamentos sociais, não se sustentaria. 
Aquilo que se chama de identidade nacional - ou, de modo genérico, identidade social - assenta na memória de um passado comum, ou pelo menos tido como comum. Por certo, o que é considerado comum, localizável ou não - e nesse último caso temos o mito fundador. (CASTANHO, 2010, p. 59).

Se, por um lado, considera-se que o passado conformado pelas tradições é buscado como um padrão para o presente, por outro, é necessário refletir sobre o caminho inverso: quando o presente se estabelece como um padrão "coercivo" para o entendimento do passado.

A busca por consolidar mudanças na sociedade faz com que, por vezes, as classes sociais emergentes defendam o presente como a expressão de toda mudança, porque o que se busca é o afastamento sistemático do passado. Esses homens passam a projetar no presente a transformação que as épocas anteriores não teriam sido capazes de gerir e aplicar em sua realidade:

O problema de se rejeitar sistematicamente o passado apenas surge quando a inovação é identificada tanto como inevitável quanto como socialmente desejável: quando isso representa o "progresso". Isso levanta duas questões distintas: como a inovação em si é identificada e legitimada, e como a situação que dela deriva será explicada. (HOBSBAWM, 2004, p. 29).

Ainda que a ideia de progresso seja um valor que a sociedade tende a adotar de forma muitas vezes desordenada, é necessário considerar que esse conceito é primeiramente relacionado ao âmbito das inovações tecnológicas que podem repercutir em uma melhoria na vida prática das pessoas. Nesse sentido, a ideia de mudança pode ser difundida no meio social primeiramente como uma facilitação na vida prática e funcional das pessoas.

Essa concepção de progresso fortalece o discurso de que toda mudança é sinônimo do tempo presente, o que, muitas vezes, simplifica as imbricações entre passado e presente, reduzindo-as a uma relação dicotômica: atraso/inovação (HOBSBAWM, 2004). 
Contudo, quando se busca analisar o sentido de mudança e transformação para além das questões que envolvem o uso da tecnologia, a exemplo dos valores culturais e sociais, tal simplificação (atraso/inovação) não se sustenta. Os valores culturais de sociedades anteriores passam a ser incorporados em meio aos embates que ocorrem no espaço social, na "arena na qual se digladiam interesses opostos gerados na contínua luta pela vida" (CASTANHO, 2010, p. 55).

Nesse âmbito, os conflitos sociais tornam-se mais intricados, pois estão em jogo forças antagônicas. Esse embate pode se estender por períodos indeterminados, pois a legitimação das transformações na cultura e na sociedade é resultante de enfrentamentos que amadureceram historicamente (MARX, 1990).

Diante de tais manifestações, o discurso em favor do progresso que reveste o presente fica fragilizado e, em muitos dos casos, esvaziado de conteúdos. Quando se tratam de transformações sociais e culturais, para além de uma acomodação prática, exigese um posicionamento mais contundente diante de mudanças tecnológicas, pois o que está em debate são transformações na própria subjetividade, naquilo que historicamente faz do homem um ser consciente de sua humanidade.

Temos conhecimento de resistência violenta a qualquer mudança nos textos sagrados antigos, mas parece não ter havido nenhuma resistência equivalente, digamos, ao barateamento de imagens e ícones sagrados por meio de processos tecnológicos modernos, tais como impressões tipográficas e oleográficas. (HOBSBAWM, 2004, p. 30).

Diante da impossibilidade de as mudanças tecnológicas serem agentes de ruptura entre passado e presente, volta-se então para uma defesa do presente como expressão de uma "justa medida" que orientaria a crítica ao passado. Na defesa do tempo presente, desconsideram-se as bases nas quais se funda o historiador em sua análise, quais sejam as da historicidade do objeto estudado (CASTANHO, 2010), desconsidera-se a 
passagem do tempo como um processo que interfere na forma de a sociedade se organizar, que transforma suas estruturas.

Ignorando-se os diferentes estágios de negociação que caracterizam cada época em relação às suas heranças culturais, desmembra-se a relação entre o acontecimento e o momento histórico e considera-se cabível um julgamento moral a respeito desse tempo pretérito:

O declínio da historicidade, ou da consciência da diacronia, leva à centralidade do sincrônico, que, para Ragazzini, é o imediato, o evento. E aí se coloca um problema epistemológico rigorosamente sem solução: como estudar o acontecimento fora de suas relações com outros eventos, como estudar uma posição ou estado de um fenômeno fora de sua processualidade, de suas determinações? (CASTANHO, 2010, p. 58).

Isolando o passado das dinâmicas sociais, políticas e econômicas, faz-se dele uma análise sentenciosa (CASTANHO, 2009), delibera-se eticamente sobre a maneira de visitá-lo. Em última instância, esse julgamento sentencioso pode dar origem a regulamentações que tiram da sociedade o direto de ter acesso a determinada memória do seu passado, especialmente quando este está revestido de um pretenso "preconceito" ou "desumanidade".

Observa-se que, em sociedades com acirrados enfretamentos sociais, as memórias a respeito do passado são objeto de disputa, já que devem ser conformadas aos interesses do presente.

Desse modo, o exercício da memória, tendo em vista a interdependência entre o individuo e a coletividade, traduz-se como uma experiência particular, que é própria do ser humano. Neste caso, entende-se que a memória, historicamente constituída, foi condição fundamental para a humanização do homem, não se reduzindo, portanto, à tarefa de se amoldar aos interesses do presente. 


\section{Passado e memória}

Ao longo da história humana, a utilização da memória colaborou em grande medida para a manutenção da sociedade ocidental: foi um recurso fundamental para as trocas culturais em tempos anteriores ao do pleno desenvolvimento da escrita. A memória, portanto, constitui-se como uma prática indispensável para a preservação da cultura.

Historicamente, o valor essencial da memória foi a sua colaboração com a organização dos afazeres cotidianos, provenientes da necessidade de manutenção da própria vida; mediando a ação do sujeito sobre a realidade que o circunda.

Ela situa-se no campo das:

[...] necessidades mais autênticas da humanidade. Seja estreito ou amplo o círculo que abarcam, elas jamais deixam o homem; Não há comunidade humana possível sem memória; toda comunidade tem, em seu devir e em sua história, uma imagem de seu ser - um bem comum de todos os que nela participaram, e que só torna sua comunhão mais sólida e íntima. (DROYSEN, 2010, p. 37).

Tal dimensão prática e coletiva da memória - insuperável à condição humana - fez dela um recurso de excelência. Seu uso para o entendimento do ritmo da natureza e dos diferentes compassos que a ação humana pode tomar, historicamente, foi uma formação necessária a todo sujeito (CASTANHO, 2010).

Acrescenta-se, assim, a complexidade conceitual que permeia a memória, que perpassa a história humana de forma distinta não só no âmbito da época a qual determinado sujeito pertence, mas dos valores da cultura ou mesmo do espaço geográfico em que está inserido - o que contribui para a permanência ou para a ruptura com determinadas concepções de temporalidade comportadas pela memória.

A exemplo, a importância da memória já era reconhecida pelos gregos, que transformaram esse atributo em uma divindade - Mnemosine -, a ela recorrendo diante da falha de suas 
lembranças a respeito dos feitos de seus grandes heróis. Dessa maneira:

É compreensível que povos extremamente bem dotados embelezem suas recordações em sagas convertidas e tipos transmissores de ideias para os quais se direciona o espírito do povo. É também compreensível que sua crença se Ihes transpareça e justifique na forma de histórias sagradas nas quais o objetivo da crença é apresentado como conteúdo real, e, assim, que o mito e a saga se desenvolvam conjuntamente. (DROYSEN, 2010, p. 37).

É necessário considerar, portanto, que a memória foi um recurso de preservação do passado épico grego, cujas narrativas sobre deuses e heróis foram se constituindo como uma memória coletiva, uma vez que passaram a ser socializadas e "embelezadas" por diferentes gerações. À memória coletiva Homero (VIII a. C.) recorreu para compilar em suas "Ilíada" e "Odisseia" os valores heroicos do homem grego (MOSSÉ, 1994), tendo em conta dignificar as virtudes cardeais do cidadão grego. ${ }^{2}$

Muitas vezes, observa-se a concepção de que a memória, por também estar situada no âmbito da subjetividade humana, seria de tal maneira fragmentada e parcial que se constitui como um "retalho" e não como um "fio" que compõe o complexo "tecido" social. As reflexões a respeito das delimitações objetivas e subjetivas da memória devem ser orientadas com base em suas dimensões culturais sem, contudo, reduzi-la a polarizações.

Ao se problematizar o passado a partir da memória, é

2 Não se quer com tal exemplificação entrar em discussão sobre os limites do uso da literatura para a escrita da História, tão pouco se pretende situar Homero como historiador de seu tempo - mesmo porque essa é uma discussão direcionada pelos padrões metodológicos da historiografia contemporânea. O que se pretendeu apontar é que, com o processo de aperfeiçoamento do uso da memória ao longo dos tempos, ela pôde se constituir como um campo em que se sustentam lembranças do passado de maneira "mais objetiva e confiável do que se poderia supor" (CASTANHO, 2010). 
necessário considerar que a mesma é seletiva e que, assim, pode expressar anacronismos quando aplicada a uma determinada realidade. É necessário considerar também as relações de poder com base nas quais a memória se constitui, o que traz implicações para o exercício de rememorar o passado, uma vez que isso pode se constituir unicamente como um exercício romântico alheio à realidade (CASTANHO, 2010).

Estas questões de ordem conceitual e teórica também se apresentam no caso da escrita da História, pois, assim como se pode diferenciar História e memória, podem-se identificar certas aproximações: ambas partem de uma seleção.

Os fatos históricos não se constituem como tais de maneira cândida como o positivismo quer inculcar. Ao revés, eles tornam-se "fatos históricos" referendados pela memória cultural na medida em que são conformados pela construção conflitiva da existência social, essa arena na qual se digladiam interesses opostos gerados na continua luta pela vida. (CASTANHO, 2010, p. 55).

A memória é requisitada não apenas por aqueles que narram o passado sem um comprometimento teórico metodológico. Em sua análise a respeito da realidade, o historiador também parte de um conhecimento que, em última instância, estabelece diálogo com a memória:

E na medida em que compilam e constituem a memória coletiva do passado, as pessoas na sociedade contemporânea têm de confiar neles (historiadores). O problema não é se elas confiam. É o que exatamente esperam obter do passado, e, nesse caso, se é isso que os historiadores deveriam Ihes dar. (HOBSBAWM, 2004, p. 37).

É necessário considerar, portanto, que a escrita da História passou por transformações de cunho teórico metodológico que tornam possível problematizar tais questões que se apresentam ao historiador. Este pode refletir para além dos valores que a memória expressa por si mesma, superando suas intencionalidades 
explícitas com base na confrontação com as demandas sociais e políticas que sustentam essa lembrança. Isso não implica desconsiderar os subsídios históricos com base nos quais essa memória pode se constituir:

Da mesma forma que não se pode julgar um indivíduo pela idéia que ele faz de si mesmo, não se poderia julgar uma época de transtornos pela consciência que ela tem em si mesma; é necessário, ao contrário, explicar esta consciência pelas contradições da vida material, pelo conflito existente entre as forças produtivas sociais e as relações de produção. (MARX, 1977, p. 168).

Considerando o exposto, entende-se que a memória é uma representação não científica do passado, o que não significa negar que, por meio dela, o homem desse tempo tenha transmitido para as gerações vindouras suas representações do mundo. Desse modo, a memória não pode se entendida como se fosse constituída pela simples individualidade, já que expressa os valores sociais e culturais vivenciados pelo sujeito e com base nos quais (CASTANHO, 2010) se faz homem.

Por ser coletiva e social, a memória também é uma vivência do historiador, embora como estudioso. Nesse caso, seu papel não é compatível com o livre exercício da memória praticado por qualquer outro cidadão (HOBSBAWM, 2004), dados o seu compromisso social e o comprometimento ao máximo com a verdade histórica, mesmo quando se põe em dúvida sua imparcialidade. O historiador deve se revestir da consciência de que o fazer histórico se constrói pela constante vigilância teórica: tais memórias podem estabelecer identificações com o estudioso, que, por isso, é levado a se comprometer de tal forma com elas que deixa de ser imparcial, acabando por assumir o discurso de sua fonte.

A memória coletiva ou individual pode, por fim, constituir-se como uma referência por meio da qual o historiador problematiza determinada realidade social e histórica. No entanto, ele deve compreender a tensão existente entre a afirmação da memória 
como um monumento à verdade e a desconstrução dessas verdades por meio de sua análise, já que são as condições concretas que dão subsídios a essas representações.

\section{Considerações finais}

O homem, com base na vida coletiva, adquire a consciência de que sua origem faz parte de um processo que não se desenvolve de maneira harmoniosa. Tem-se em vista que o sujeito faz parte de um contexto de constantes enfrentamentos sociais, participando de embates que transitam desde a sistemática negação de seu passado até as negociações com suas tradições, que teimam em ser perenes e efetivas. Dessa maneira, a forma como o passado é concebido no seio da sociedade é constantemente afetada pelo presente. Uma vez que, em cada época histórica, o homem encontra novas exigências para a manutenção de sua existência social e política, ele opera transformações nas formas de se inserir no continuum da existência humana.

Essa dinâmica expressa a complexidade das relações humanas e se constitui como um processo legítimo, embora possam ocorrer tentativas de se "reconstruir" o passado em momentos em que os enfrentamentos sociais se tornam mais acirrados.

Resta, por fim, um alerta ao historiador: ao se voltar para o estudo de períodos históricos marcados por profundos embates, ele pode assumir as polaridades expressas pelos sujeitos em questão: conservação/transformação. Por isso, primeiramente, ele precisa compreender tais discursos com base em suas condicionantes sociais e históricas.

\section{Referências}

ATTALI, Jacques. Historias del tempo. México: FCE, 1985.

BURCKHARDT, Jacob. História da cultura grega. In: MARTINS, Estevão de Rezende (Org.). História pensada. São Paulo: Editora Contexto, 2010. p. 159-178. 
CASTANHO, Sérgio. Reação ao declínio da consciência histórica: comentários sobre o texto "Diacrônico/sincrônico e os paradoxos educativos da historiografia”. In: LOMBRADI, José Claudinei; SAVIANI, Dermeval (Orgs.). Navegando pela história da educação brasileira: 20 anos de Histedbr. São Paulo: Autores Associados, 2009.

. Teoria da história da educação: por uma história cultural não culturalista. Campinas: Autores Associados, 2010.

DROYSEN, Johann Gustav. Arte e método. In: MARTINS, Estevão de Rezende (Org.). História pensada. São Paulo: Editora Contexto, 2010. p. 31-46.

HOBSBAWM, E. Era dos extremos: o breve século XX: 1914-1991. São Paulo Companhia das Letras, 2010.

. Sobre história. São Paulo Companhia das Letras, 2004.

MARX, Karl; ENGELS, Friedrich. Manifesto do Partido Comunista. Petrópolis: Vozes, 1990.

MARX, Karl. Contribuição à crítica da economia política. São Paulo: Martins Fontes, 1977.

. Crítica ao Programa de Gotha. Observações sobre o Programa do Partido Operário Alemão. In: RICARDO, Antunes (Org). A dialética do trabalho. Escritos de Marx e Engels. São Paulo. Expressão Popular, 2004.

e Terra, 1986.

Formações econômicas pré-capitalistas. 5. ed. São Paulo. Paz O 18 brumário e carta a Kugelmann. 6. ed. Rio de Janeiro: Paz e Terra, 1997.

MOSSÉ, Claude. A Grécia arcaica de Homero a Ésquilo. Lisboa: Edições 70, 1994.

PEREIRA MELO, José Joaquim. A educação paleo-cristã. Teoria e Prática da Educação, Maringá, v. 4, n. 9, p. 94-107, 2002. 
PEREIRA MELO, José Joaquim.. Fontes e métodos: sua importância na descoberta das heranças educacionais. In: COSTA, Célio Juvenal; PEREIRA MELO, José Joaquim; FABIANO, Luiz Hermenegildo (Orgs.). Fontes e métodos em história da educação. Dourados: UFGD, 2010. p. 13-34.

PIKE, E. R. Human documents of the Industrial Revolution in Britain. London: George Allen \& Unwin, 1974.

SAINT-JUST, L. A. L. O espírito da revolução. São Paulo: Ed. da UNESP, 1996.

Recebido em agosto de 2016.

Aprovado em junho de 2017. 